\title{
The Roles of Need for Achievement and Family Environment in Stimulating Entrepreneurial Interest through Self-Efficacy
}

\author{
Fiarika Dwi Utari ${ }^{*}$, Sukidjo \\ ${ }^{12}$ Universitas Negeri Yogyakarta, Indonesia \\ 1fiarikadwiutari.2017@uny.student.ac.id, ${ }^{2}$ sukidjo@uny.ac.id, *corresponding author
}

\begin{abstract}
This study was designed to reveal the extent to which the need for achievement and family environment affected entrepreneurial interest through self-efficacy, either directly or indirectly. It used causal associative research with a quantitative approach and drew on information collected from 322 samples selected using the proportional random sampling from a study population of 4.570 students of Yogyakarta State University. The research data were collected using a questionnaire that had been tested for validity and reliability and then analyzed using the path analysis. The results showed that the need for achievement and family environment, directly and indirectly, increased entrepreneurial interest through self-efficacy.
\end{abstract}

Keywords: entrepreneurial interest, family environment, need for achievement, self-efficacy

\section{Peran Kebutuhan akan Prestasi dan Lingkungan Keluarga terhadap Minat Berwirausaha melalui Efikasi Diri}

\begin{abstract}
Abstrak
Penelitian ini bertujuan untuk mengetahui peran kebutuhan akan prestasi dan lingkungan keluarga terhadap minat berwirausaha melalui efikasi diri baik secara langsung maupun tidak langsung. Penelitian ini termasuk penelitian asosiatif kausal dengan pendekatan kuantitatif. Populasi penelitian terdiri dari 4.570 mahasiswa Universitas Negeri Yogyakarta. Adapun jumlah sampel terdiri dari 322 mahasiswa yang ditentukan dengan teknik proportional random sampling. Metode pengumpulan data menggunakan angket yang telah diuji validitas dan reliabilitasnya. Teknik analisis data yang digunakan adalah analisis jalur. Hasil penelitian menunjukkan bahwa kebutuhan akan prestasi dan lingkungan keluarga meningkatkan minat berwirausaha baik secara langsung maupun tidak langsung melalui efikasi diri.
\end{abstract}

Kata Kunci: efikasi diri, kebutuhan akan prestasi, lingkungan keluarga, minat berwirausaha

\section{INTRODUCTION}

Unemployment is among the ubiquitous social problems affecting a country's growth and development (Okoro et al., 2019). It occurs following an imbalance between available workforce and job opportunities, in which the former is present in a higher number than the letter. Besides, regional growth in the digital era increasingly requires the development of quality human resources (Ibegbulam \& Echezona, 2019).

According to the statistics BPS-Statistics Indonesia (2019), the number of unemployed college graduates nationwide is still relatively high, even though students have been prepared for work competition. In reality, it is an irony that higher education does not necessarily guarantee easy employment (Sani \& Bin Jamil, 2019).

Unemployment rates can be reduced by building confidence in entrepreneurship (Bakry, et al., 2019), a known solution to problems arising from intellectual unemployment 
(Matthew \& Victor, 2018). Fostering entrepreneurial spirit or mindset at formal education institutions is believed to be an alternative to reducing unemployment rates because it educates students as young entrepreneurs who can start and run their businesses (Youssef et al., 2018). However, student's interest in entrepreneurship is still low (Osakede et al., 2017), and as such, it needs immediate concerns and attention from various parties, including governments, education, industrial sectors, and society (Arrifianti \& Hamdi, 2016).

Entrepreneurship is crucial in economic development because it can act as a transformational driver to achieve sustainable development goals (Apostolopoulos et al., 2018; Fayolle \& Liñán, 2014; Mat, Maat \& Mohd, 2015; Soomro \& Shah, 2015) Therefore, increasing entrepreneurial interest becomes necessary. Entrepreneurial interest can be defined as a state of mind that directs attention and action towards entrepreneurial activities (Fayolle \& Gailly, 2015). According to Hendro (2011), many factors influence entrepreneurial interest, including (1) personal characteristics, (2) education, (3) family encouragement, (5) compulsion, and circumstances. Also, achievement as motives, optimism, values, and the status of entrepreneurial success determines such interest. To stimulate and increase entrepreneurial motivation, pedagogy should emphasize developing students' psychological and social entrepreneurial skills by incorporating the emotional and critical thinking (Farhangmehr et al., 2016; Ismail, et al., 2015). Entrepreneurial behavior, a determinant of entrepreneurial success, is a product of internal and external factors; internal factors are ownership rights, abilities/competencies, and incentives, while external factors include conditions of the environment like government policies, the existence of role models, opportunities, competitors, resources, and activities. Thus, based on a number of theories, many known variables influence entrepreneurial interest, and this research selected three variables: the need for achievement, family environment, and self-efficacy.

Entrepreneurial interest can grow by increasing the need for achievement (EspírituOlmos \& Sastre-Castillo, 2015; Joseph, 2017; Karabulut, 2016). According to Hasibuan et al., (2019), entrepreneurial interest can be seen as an intention to create or start a new venture that requires taking risks. It also stems from the attitude of reacting effectively to any potential risks in business, which will later shape a person's interest in becoming an entrepreneur (Ermawati, et al., 2017). The need for achievement refers to a person's desire to work on difficult challenges and make risky decisions to succeed in entrepreneurship (Chaudhary, 2017). According to Rokhman \& Ahamed (2015), it is a psychological driving factor and a strong characteristic behind a person's actions and has long been recognized as a factor influencing entrepreneurial behavior. Also, it is defined as the desire to perform the best, be successful, and feel competent efforts (Barba-Sánchez \& Atienza-Sahuquillo, 2012; Do \& Dadvari, 2017). With the need for achievement, students have a strong desire to be involved in entrepreneurial activities (Zeffane, 2013) and eventually find ways to become entrepreneurs, notably because this sector's success rate is relatively high (Yimamu, 2018).

The family environment is among the factors influencing entrepreneurial interest. Parents play a critical part in determining the students' future (Farrukh et al., 2017). Ambad \& Damit (2016) confirm that family members can be seen as role models and, thus, 
significantly affect children's career choices. In addition to being role models, they also provide economic and emotional support to aspiring entrepreneurs (Arrighetti et al., 2016). For these reasons, the family environment influences students' decisions in conducting entrepreneurial activities (Mustapha \& Selvaraju, 2015).

Self-efficacy is also an essential factor in determining entrepreneurial interest (Piperopoulos \& Dimov, 2014; Şahin et al., 2019; Santos \& Liguori, 2019). It refers to a person's belief in his/her ability to start and run a business (Hsu et al., 2019). However, most people may avoid or seldom engage in certain critical entrepreneurial activities because of a lack of self-efficacy (Bandura, 1977; Chen et al., 1998). Therefore, self-efficacy can only produce favorable results if people believe in their entrepreneurship skills and capacity (Chowdhury et al, 2019). In particular, (Solesvik, 2017) states that self-efficacy can lead to higher entrepreneurial interest when combined with personal initiatives.

\section{Influence of Need for Achievement on Self-Efficacy}

Students highly motivated by achievements will always attempt to maximize their abilities and skills to achieve a goal (Sheldon et al., 2019), and this can stimulate another internal psychological factor, namely self-efficacy (Locke, 1996). Bandura (1977) said that it is not enough for someone to depend on their desire to take action without the belief to achieve their goals. To become an entrepreneur, the need for achievement and self-efficacy are inevitable since students should constantly aim for goals by always trying to improve performance and be responsible for their work outcomes and should be able to face challenging tasks (Utsch \& Rausch, 2010). Both factors positively correlate with achieving goals (Phillips \& Gully, 1997), affect expenditure effort and task persistence, and have emotional effects (Bandura et al, 1982).

$\mathrm{H}_{1}$ : Need for achievement has a positive influence on self-efficacy

\section{Influence of Family Environment on Self-Efficacy}

The family environment provides experience and social persuasion that shape personality (Ahun et al., 2017). Support from loved ones tends to have a more significant direct effect on self-efficacy than other contextual factors (Garcia et al., 2015; Wright et al., 2014). Family indeed creates an environment that determines whether or not self-efficacy can grow (Mauer et al., 2017).

$\mathrm{H}_{2}$ : Family environment has a positive influence on self-efficacy

\section{Influence of Need for Achievement on Entrepreneurial Interest}

The need for achievement is a strong psychological driving factor behind a person's actions and a known determinant of entrepreneurial behavior (Altinay et al., 2012; Asmara et al., 2016; Joseph, 2017). In this context, a high need for achievement means having an obsession with becoming an entrepreneur (Zhou et al., 2018). It can be concluded that the need for achievement affects entrepreneurial success: the higher the former, the greater the latter (Sabiu et al., 2018; Viinikainen et al., 2017).

$\mathrm{H}_{3}$ : Need for achievement has a positive influence on entrepreneurial interest 


\section{Influence of Family Environment on Entrepreneurial Interest}

The family environment creates an environment in which students grow (Hutagalung et al., 2017). Families, especially parents, play a vital role in helping students prepare themselves and make career choices and decisions (Pizzorno et al., 2014). They also act as advisors to the student's future, which indirectly affects their interest in certain professions, like entrepreneurs. Entrepreneurial interest is most likely to grow among families with positive support and stand toward entrepreneurship (Altinay et al., 2012). Parental entrepreneurship allows students to be more familiar with various entrepreneurial skills to acquire and tasks to complete as a successor to the family business or even in starting their own ventures (Mauer et al., 2017; Palmer et al., 2019).

$\mathrm{H}_{4}$ : Family environment has a positive influence on entrepreneurial interest

\section{Influence of Self-Efficacy on Entrepreneurial Interest}

Self-efficacy is defined as a person's belief in his/her ability to complete work, achieve goals, and overcome obstacles and challenges (Bellò et al., 2017). It is an inevitable element required to start and run a business (Dardiri et al., 2019; Frunzaru \& Cismaru, 2018). Besides, it can increase students' confidence in their ability to succeed in entrepreneurship and launch new businesses (Fuller et al., 2018; Mei et al., 2017). Students with high selfefficacy are more likely to face challenges well and make efforts to carry out successful business (Hemmings, 2018).

$\mathrm{H}_{5}$ : Self-efficacy has a positive influence on entrepreneurial interest

\section{Influence of Need for Achievement on Entrepreneurial Interest through Self-Efficacy}

According to McClelland (1965), the need for achievement is the desire to perform good things aimed at personal achievement. It also plays a role in decision-making processes and risk-taking attitudes (Farrukh et al., 2018). Therefore, apart from the need for achievement, aspiring entrepreneurs also need to have self-efficacy (Farhangmehr et al., 2016). Both factors are vital because planning, starting, and running a business takes persistence, selfregulation, and emotional control, particularly in dealing with uncertainty, risk, and many demands in entrepreneurship (Wartiovaara et al., 2019). Mahmood et al. (2019) also confirm that the need for achievement and self-efficacy are the key determinants of entrepreneurial interest among students.

$\mathrm{H}_{6}$ : The need for achievement has a positive influence on entrepreneurial interest through self-efficacy

\section{Influence of Family Environment on Entrepreneurial Interest through Self-Efficacy}

Family plays a critical role in shaping children's personality and character (Hutagalung et al., 2017). Inspiration and perceived support from family members can increase their selfefficacy (Kazeem \& Asimiran, 2016), and confidence in a successful future will promote self-confidence in decision making, including pursuing entrepreneurship as careers (Apriliana \& Djatmika, 2017). 
$\mathrm{H}_{7}$ : Family environment has a positive influence on entrepreneurial interest through selfefficacy

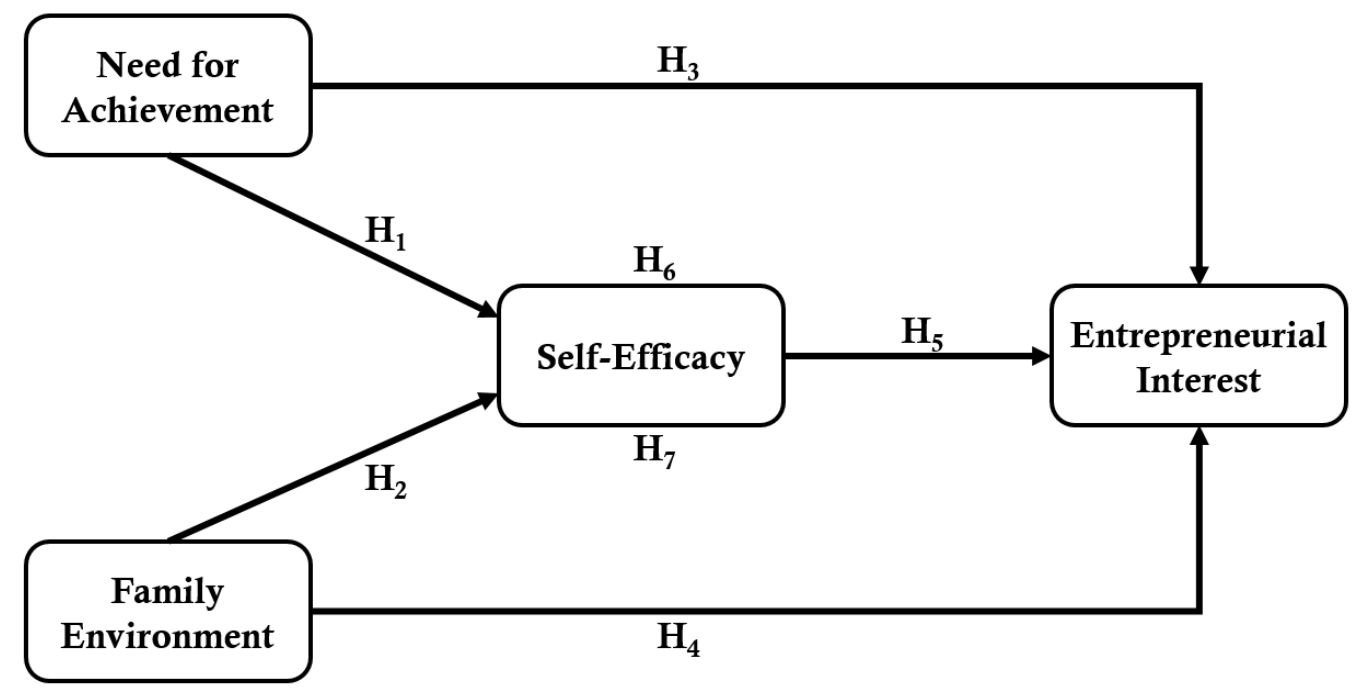

Figure 1. Research paradigm linking the need for achievement, family environment, selfefficacy, and entrepreneurial interest

\section{METHOD}

This causal associative research used a quantitative approach and collected information from 322 samples selected from a population of 4,570 undergraduate students of Yogyakarta State University with a proportional random sampling. Of these samples, 59\% were female, and $41 \%$ were male, which were distributed in even faculties: Language and Arts (18\%), Economics (9.5\%), Sports Science (10\%), Education (18\%), Social Sciences (13.5\%), Mathematics and Natural Sciences (16\%), and Engineering (15\%).

The data were collected using a questionnaire that had been tested for validity and reliability. In this study, entrepreneurial interest was measured using four indicators: 1) choosing self-employment over regular employments (i.e., working with other people) (Ramayah \& Harun, 2005); 2) deciding to pursue a career as an entrepreneur (Ramayah \& Harun, 2005); 3) possessing future-oriented mindset (Agustini, 2007); and 4) planning to start a business (Yanti et al., 2014). As for the need for achievement, this factor was measured using six indicators: 1) having the ability to complete new tasks that are more difficult than previous assignments (Larsen \& Buss, 2018); 2) enjoying duties that involve personal responsibility (Larsen \& Buss, 2018); 3) enjoying tasks that have feedback (Larsen \& Buss, 2018); 4) giving their best in completing difficult tasks (Indarti \& Rostiani, 2008); 5) trying to perform better than others (Indarti \& Rostiani, 2008); and 6) encouraging achievement (Yuhendri, 2014). The family environment indicators were 1) parents' knowledge of entrepreneurship (Ratumbuysang \& Rasyid, 2015); 2) parents' mindset about entrepreneurship (Slameto, 2010); 3) support from families to become self-employed (Slameto, 2010); 4) parents' education (Slameto, 2010); 5) relationship between family members (Yanti, Nuridja, \& Dunia, 2014); and 6) family's economic condition (Slameto, 2010). The self-efficacy indicators were 1) confidence in the ability to manage a business (Andika \& Madjid, 2012); 2) high leadership qualities, especially in starting a business (Munawar, 2019); and 3) emotional condition (Bandura, 2012).

The collected data were analyzed using the path analysis to determine the influence of the need for achievement and family environment on entrepreneurial interest through selfefficacy, either directly or indirectly. Path analysis was carried out in the AMOS version 20.0 program. 
Jurnal Economia, 16(2), October 2020, 143-160

\section{FINDINGS AND DISCUSSION}

\section{Validity and Reliability Test Results}

A confirmatory factor analysis on a pilot sample $(n=200)$ was conducted to assess the construct validity. Based on the results, two questionnaire items describing entrepreneurial interest were not valid, while the other 11 items were determined as research instruments. As for the 'need for achievement' and 'family environment' variables, two questionnaire items of each were not valid, leaving 18 items as research instruments. Meanwhile, all 14 questionnaire items of self-efficacy were deemed valid and, thus, qualified as research instruments. In total, there were 61 questionnaire items used to measure each research variable.

The reliability test used Cronbach's Alpha to identify internal consistency. Based on the pilot test results ( $\mathrm{n}=200$ samples), the reliability of each research variable is summarized in Table 1.

Table 1. Reliability Test Results

\begin{tabular}{cc}
\hline Variables & Cronbach's Alpha \\
\hline Entrepreneurial Interest & 0.776 \\
Need for Achievement & 0.868 \\
Family Environment & 0.895 \\
Self-Efficacy & 0.717 \\
\hline
\end{tabular}

Based on research data calculation, the descriptive statistics of each variable are shown in Table 2.

Table 2. Descriptive Statistics

\begin{tabular}{lccccc}
\hline & $\mathrm{N}$ & Minimum & Maximum & Mean & Std. Deviation \\
\hline EI & 322 & 2.45 & 4.00 & 3.2684 & .36513 \\
NFA & 322 & 2.00 & 4.00 & 3.0747 & .37326 \\
FE & 322 & 1.78 & 4.00 & 2.9173 & .44010 \\
SE & 322 & 2.21 & 4.00 & 3.0775 & .37805 \\
\hline Valid N (listwise) & 322 & & & &
\end{tabular}

Notes: EI=entrepreneurial interest; $N F A=$ need for achievement; $F E=$ family environment; $S E=$ self-efficacy.

Before analysis, the collected data were first examined to see whether they met these requirements: a linear relationship between variables, normally distributed data, no multicollinearity, and no offending estimate. Afterward, the overall model fit assessment was carried out using various criteria. The goodness of fit (GOF) measures the extent to which observational or actual inputs match the predictions of the proposed model (Ghozali, 2017). Table 3 presents the results of the GOF's absolute fit measures.

Table 3. The Results of the Goodness of Fit

\begin{tabular}{lccc}
\hline \multicolumn{1}{r}{ Criteria } & Standards of Measurement & \multicolumn{2}{c}{ Results } \\
\hline $\mathrm{X}^{2}$ & Low & 0.000 & Good Fit \\
GFI & $\geq 0.90$ & 1.000 & Perfect Fit \\
RMSEA & $<0.8$ & - & - \\
NFI & $\geq 0.90$ & 1.000 & Perfect fit \\
\hline
\end{tabular}


Notes: $X^{2}=$ chi-square; $G F I=$ goodness-of-fit index; $R M S E A=$ root mean square error of approximation; $N F I=$ normed fit index.

The goodness-of-fit test yielded a chi-square value of 0.000 (indicating a fit model), a GFI value of 1.000 (perfect fit), and an NFI value of 1.000 (perfect fit). However, the RMSEA value did not appear. Overall, it can be inferred that the model is statistically fit.

The path analysis measured the extent of the two variables' direct and indirect effects (i.e., the need for achievement and family environment) on entrepreneurial interest through self-efficacy. It also decides whether the research hypotheses are accepted or rejected based on $\mathrm{CR}$ and $\mathrm{P}$ values (Table 4). The hypothesis is accepted if $\mathrm{CR}>1.995$ and $\mathrm{P}<0.05$

Table 4. Path Analysis Results

\begin{tabular}{|c|c|c|c|c|c|c|}
\hline & & & Estimates & $\mathrm{SE}$ & CR & $\mathrm{P}$ \\
\hline $\mathrm{SE}$ & $\leftarrow$ & $\mathrm{FE}$ & .204 & .042 & 4.898 & $* * *$ \\
\hline SE & $\leftarrow$ & NFA & .566 & .049 & 11.517 & $* * *$ \\
\hline EI & $\leftarrow$ & SE & .461 & .047 & 9.818 & $* * *$ \\
\hline $\mathrm{EI}$ & $\leftarrow$ & $\mathrm{FE}$ & .174 & .036 & 4.770 & $* * *$ \\
\hline EI & $\leftarrow$ & NFA & .217 & .049 & 4.415 & $* * *$ \\
\hline \multicolumn{3}{|c|}{ Variables } & \multicolumn{4}{|c|}{$\mathrm{R}^{2}$} \\
\hline \multicolumn{3}{|c|}{$\mathrm{SE}$} & \multicolumn{4}{|c|}{.534} \\
\hline \multicolumn{3}{|c|}{ EI } & \multicolumn{4}{|c|}{.646} \\
\hline
\end{tabular}

Notes: EI=entrepreneurial interest; $N F A=n e e d$ for achievement; FE=family environment; SE=self-efficacy; $R^{2}=$ coefficient of determination; $C R=$ critical ratio; $P=$ probability.

In addition to $\mathrm{CP}$ and $\mathrm{P}$, the path analysis produced coefficients of determination $\left(\mathrm{R}^{2}\right)$, which describe the effects of exogenous variables on endogenous variables. The combined influence of the need for achievement and family environment on self-efficacy was $\mathrm{R}^{2}=0.534$. Meanwhile, the combined influence of the need for achievement, family environment, and self-efficacy on entrepreneurial interest was $\mathrm{R}^{2}=0.646$. Furthermore, a Sobel test was conducted to determine the indirect effects of the independent variables (need for achievement and family environment) on the dependent variable (entrepreneurial interest) through the intervening variable (self-efficacy). t-value $<1.96$ indicates a significant indirect effect. Table 5 presents the Sobel test results.

Table 5. Sobel Test Results

\begin{tabular}{clllll}
\hline & & & & & $\mathrm{t}$ \\
\hline $\mathrm{NFA}$ & $\rightarrow$ & $\mathrm{SE}$ & $\rightarrow$ & EI & $7.4764^{*}$ \\
$\mathrm{FE}$ & $\rightarrow$ & $\mathrm{SE}$ & $\rightarrow$ & EI & $4.3338^{*}$ \\
\hline
\end{tabular}

Notes: $E I=$ entrepreneurial interest; $N F A=$ need for achievement; $F E=$ family environment; $S E=$ self-efficacy; $t^{*}>1.96$.

This research was designed to determine (1) the direct effects of the need for achievement and family environment on self-efficacy, (2) the direct effects of the need for achievement, family environment, and self-efficacy on entrepreneurial interest, and (3) the indirect effects of the need for achievement and family environment on entrepreneurial interest through self-efficacy. In this study, the roles of the need for achievement and family environment in stimulating entrepreneurial interest through self-efficacy were analyzed using path analysis. Table 6 summarizes the results of the hypothesis testing.

Table 6. Summary of the hypothesis testing results 
Jurnal Economia, 16(2), October 2020, 143-160

\begin{tabular}{|c|c|c|c|c|c|c|c|c|}
\hline \multicolumn{6}{|c|}{ Hypotheses } & CR $(>1.995)$ & $t(>1.96)$ & Results \\
\hline $\mathrm{H}_{1}$ : & NFA & $\rightarrow$ & $S E$ & & & $11.517^{*}$ & & accepted \\
\hline $\mathrm{H}_{2}$ : & $F E$ & $\rightarrow$ & $S E$ & & & $4.898^{*}$ & & accepted \\
\hline $\mathrm{H}_{3}$ : & $N F A$ & $\rightarrow$ & $E I$ & & & $4.415^{*}$ & & accepted \\
\hline $\mathrm{H}_{4}$ : & $F E$ & $\rightarrow$ & $E I$ & & & $4.770^{*}$ & & accepted \\
\hline $\mathrm{H}_{5}$ : & $S E$ & $\rightarrow$ & $E I$ & & & $9.818^{*}$ & & accepted \\
\hline $\mathrm{H}_{6}$ : & $N F A$ & $\rightarrow$ & $S E$ & $\rightarrow$ & EI & & 7.4764 & accepted \\
\hline $\mathrm{H}_{7}$ : & $F E$ & $\rightarrow$ & $S E$ & $\rightarrow$ & EI & & 4.3338 & accepted \\
\hline
\end{tabular}

Notes: EI=entrepreneurial interest; $N F A=$ need for achievement; $F E=$ family environment; $S E=$ self-efficacy; ${ }^{*} p<0.05$.

Table 6 shows that the need for achievement has a positive and significant effect on self-efficacy, as indicated by the critical ratio (CR) of 11.517 and $p<0.05$. This result is consistent with (Phillips \& Gully, 1997), and it means that the higher the student's need for achievement, the higher their self-efficacy. In other words, maximizing the former will also increase the latter (Locke, 1996). Self-efficacy also affects task persistence and can have emotional effects (Bandura et al., 1982; Wartiovaara et al., 2019).

The family environment positively and significantly affects self-efficacy, as evidenced by $C R=4.898$ and p-value $<0.05$. Research by (Mauer et al., 2017; Memon et al., 2019; Wang et al., 2018) also show similar results. A family environment provides a place for children to start their life and greatly influences their developing personalities (Ahun et al., 2017). Feist \& Feist (2017) define self-efficacy as a person's belief in his/her abilities to control the benefits obtained and the conditions in the surrounding environment. Therefore, considering that family members are the sources of motivation and confidence, the family environment substantially influences students' self-confidence.

The need for achievement has a positive and significant effect on entrepreneurial interest, as evident from $C R=4.415$ and $p<0.05$. Espíritu-Olmos \& Sastre-Castillo (2015) and Ferreira et al. (2012) revealed that the need for achievement significantly determines a person's entrepreneurial interest. It is a psychological driving factor that underlies students' actions and a determinant of entrepreneurial behavior (Altinay et al., 2012; Asmara et al., 2016; Joseph, 2017). Popescu et al. (2016) added that the need for achievement needs to be assessed to stimulate students' interest in starting entrepreneurial activities in the future. In short, it determines whether students can succeed in entrepreneurship. The higher the need for achievement, the higher the student's entrepreneurial interest (Sabiu et al., 2018; Viinikainen et al., 2017).

The family environment positively and significantly influences entrepreneurial interest, as apparent from $C R=4.770$ and $p<0.05$. This result is in line with Adnan (2017), Marini \& Hamidah (2014), Mustapha \& Selvaraju (2015), and Wang et al. (2018). Interest in pursuing self-employment can be grown only if the family also gives positive support (Altinay et al., 2012; Campopiano et al, 2016). Parental entrepreneurship (an integral part of the family environment) can foster interest and encourage students to become entrepreneurs (Palmer et al., 2019).

Like the need for achievement and family environment, self-efficacy positively and significantly influences entrepreneurial interest, as evident from $C R=9.770$ and $\mathrm{p}<0.05$. This result is consistent with previous studies by Hermawan et al. (2016), Hutasuhut (2018), and Liguori et al. (2017). Students with high self-efficacy also have self-confidence in performing a job or completing even a difficult task. Self-efficacy can increase students' assessment of their own ability to display reactions, thus accelerating and facilitating students to become self-employed (Schmutzler et al., 2019). Bandura (2012) explains that entrepreneurial self-efficacy affects students' motivation and competence to enter a more 
challenging process, i.e., to start a business, and shows their academic preparation for future career paths as entrepreneurs. Therefore, the higher the self-efficacy, the higher the entrepreneurial interest.

The results showed that the need for achievement indirectly affected entrepreneurial interest through self-efficacy, as evidenced by $t=7.4764(>1.96)$. It is consistent with Kerr et al. (2019). The need for achievement is one of the personality traits that will encourage students to have an entrepreneurial interest (Altinay et al., 2012; Joseph, 2017). It also shapes their decision-making processes, desires, and courage or confidence in taking and responding to the risks at hand Tong et al. (2011). To become entrepreneurs, students also need to have high self-efficacy, which is related to the belief in his/her abilities (Aslam \& Hasnu, 2016) and, consequently, determines their way of thinking, persistence in action, and ability to motivate themselves when facing difficulties (Asmara et al., 2016). Dalimunthe et al. (2019) also revealed that self-efficacy greatly affects students' motivation to achieve success or goals. In other words, high self-efficacy is associated with increased expectations, goals, and work-related performance (Cassar \& Friedman, 2009). When combined with a high need for achievement, it contributes to increased entrepreneurial interest, trust in business management, and confidence in starting a new venture or company (Wartiovaara et al., 2019). The higher the self-efficacy in entrepreneurship, the stronger the entrepreneurial interest. The need for achievement includes human mental strength to perform better, faster, more effective, and more efficient activities than previous ones. In short, the high need for achievement will increase student's self-efficacy in entrepreneurship.

The results showed that the family environment indirectly influenced entrepreneurial interest through self-efficacy, as indicated by $\mathrm{t}=4.3338$ (>1.96). It is consistent with Indriyani \& Subowo (2013) and Wu et al. (2019). Students receiving support from their parents and their family environment will be well-prepared for self-employment challenges (Ayyubi et al., 2018). In other terms, a family environment that supports students to become entrepreneurs is most likely to elevate their self-efficacy in carrying out entrepreneurial activities.

\section{CONCLUSION}

First, the study results indicate that the need for achievement has a positive and significant effect on self-efficacy; thus, maximizing this variable will further increase self-efficacy. Second, the family environment is proven to positively and significantly affect self-efficacy, meaning that good family environments promote high self-efficacy, and vice versa. Third, the need for achievement has a positive and significant effect on entrepreneurial interest; the higher the need for achievement, the higher the entrepreneurial interest. Fourth, the family environment is reported to positively and significantly influences entrepreneurial interest. The family environment will foster entrepreneurial interest, and family is a significant determinant of students' interests in entrepreneurship. Fifth, self-efficacy has a positive and significant effect on entrepreneurial interest, implying that high self-efficacy is followed by high entrepreneurial interest. Sixth, the study results indicate that the need for achievement indirectly influences entrepreneurial interest through self-efficacy; thus, instilling a high need for achievement into students' mindset can increase their confidence or self-efficacy in entrepreneurship. Seventh, the family environment indirectly affects entrepreneurial interest through self-efficacy; in other terms, a good family environment 
Jurnal Economia, 16(2), October 2020, 143-160

that supports students to become entrepreneurs is most likely to increase or shape their confidence in performing entrepreneurial activities.

\section{ACKNOWLEDGMENTS}

The authors would like to thank the lecturers for their guidance, encouragement, and constructive advice during this article's writing. The authors would also like to thank the faculty, staff, and undergraduate students of Yogyakarta State University for their invaluable help in the smooth running of this research so that this article can be completed properly and on time.

\section{REFERENCES}

Adnan, A. Z. (2017). Pengaruh Kepribadian Wirausaha, Pengetahuan Kewirausahaan, dan Lingkungan terhdap Minat Berwirausaha Mahasiswa/i Akademi Minyak dan Gas Balongan Indramayu Jawa Barat. Syntax Literate: Jurnal Ilmiah Indonesia, 2(10), 1-6.

Agustini, F. (2007). Peningkatan Motivasi, Hasil Belajar dan Minat Berwirausaha Siswa melalui Pembelajaran Kimia dengan Pendekatan Chemoentreprenerurship (CEP). Universitas Negeri Semarang.

Ahun, M. N., Consoli, A., Pingault, J.-B., Falissard, B., Battaglia, M., Boivin, M., Tremblay, R. E., \& Côté, S. M. (2017). Maternal depression symptoms and internalising problems in the offspring: the role of maternal and family factors. European Child and Adolescent Psychiatry, 27(7), 921-932. https://doi.org/10.1007/s00787-017-1096-6.

Altinay, L., Madanoglu, M., Daniele, R., \& Lashley, C. (2012). The influence of family tradition and psychological traits on entrepreneurial intention. International Journal of Hospitality Management, 31(2), 489-499. https://doi.org/10.1016/j.ijhm.2011.07.007.

Ambad, S. N. A., \& Damit, D. H. D. A. (2016). Determinants of Entrepreneurial Intention Among Undergraduate Students in Malaysia. Procedia Economics and Finance, 37(16), 108-114. https://doi.org/10.1016/s2212-5671(16)30100-9.

Andika, M., \& Madjid, I. (2012). Analisis Pengaruh Sikap, Norma Subyektif dan Efikasi Diri terhadap Intensi Berwirausaha pada Mahasiswa Fakultas Ekonomi Universitas Syiah Kuala. Eco Entrepreneurship Seminar \& Call for Paper "Improving Performance by Improving Environment," 190-197. https://doi.org/10.1007/978-1-4419-0143-0.

Apostolopoulos, N., Al-Dajani, H., Holt, D., Jones, P., \& Newbery, R. (2018). Entrepreneurship and the sustainable development goals. Contemporary Issues in Entrepreneurship Research, 8, 1-7. https://doi.org/10.1108/s2040724620180000008005 .

Apriliana, A., \& Djatmika, E. T. (2017). Effect of Student Participation in Business Center, Parent'S Role, and Self-Efficiency To Entrepreneurship Intention Students of Smk. Jurnal Pendidikan Bisnis Dan Manajemen, 3(3), 167-178. https://doi.org/10.17977/um003v3i32017p167.

Arrifianti, I., \& Hamdi, N. (2016). Faktor-Faktor yang Mempengaruhi Motivasi 
Mahasiswa Ingi Menjadi Wirausaha (Studi Kasus pada Mahasiswa STIE AMM Mataram). Jurnal Valid, 13(1), 73-82. https://doi.org/10.1186/s13731-017-0079-7.

Arrighetti, A., Caricati, L., Landini, F., \& Monacelli, N. (2016). Entrepreneurial intention in the time of crisis: a field study. International Journal of Entrepreneurial Behaviour and Research, 22(6), 835-859. https://doi.org/10.1108/IJEBR-12-2015-0326.

Aslam, S., \& Hasnu, S. (2016). Issues and constraints perceived by young entrepreneurs of Pakistan. World Journal of Entrepreneurship, Management and Sustainable Development, 12(1). https://doi.org/10.1108/WJEMSD-03-2015-0015.

Asmara, H. W., Djatmika, E. T., \& Indrawati, A. (2016). The Effect of Need for Achievement and Risk Taking Propensity on Entepreunerial Intention through Entepreunerial Attitude. IOSR Journal of Business and Management, 18(6), 117-126. https://doi.org/10.9790/487X-180601117126.

Ayyubi, W. U. Al, Setyanti, S. W. L. H., \& Suroso, I. (2018). The Role of Self Efficacy as Mediating The Influence of Family Environment and Social Environment on Student Entrepreneur Interest. International Journal of Scientific and Technology Research, 7(7), 3339.

Bakry, D., Khalifa, R., \& Dabab, M. (2019). The effectiveness of entrepreneurship programs to reduce unemployment in developing countries: The case of Saudi Arabia. PICMET 2019 - Portland International Conference on Management of Engineering and Technology: Technology Management in the World of Intelligent Systems, Proceedings. https://doi.org/10.23919/PICMET.2019.8893678.

Bandura, A. (1977). Self-Efficacy: Toward a Unifying Theory of Behavioral Change. Revisión Psicológica, 84(2), 191-215. https://doi.org/10.1037/0033-295X.84.2.191.

Bandura, A. (2012). On the functional properties of perceived self-efficacy revisited. Journal of Management, 38(1), 9-44. https://doi.org/10.1177/0149206311410606.

Bandura, A., Reese, L., \& Adams, N. E. (1982). Microanalysis of action and fear arousal as a function of differential levels of perceived self-efficacy. Journal of Personality and Social Psychology, 43(1), 5-21. https://doi.org/10.1037/0022-3514.43.1.5.

Barba-Sánchez, V., \& Atienza-Sahuquillo, C. (2012). Entrepreneurial behavior: Impact of motivation factors on decision to create a new venture. Investigaciones Europeas de Direccion y Economia de La Empresa, 18(2), 132-138. https://doi.org/10.1016/S11352523(12)70003-5.

Bellò, B., Mattana, V., \& Loi, M. (2017). The power of peers: A new look at the impact of creativity, social context and self-efficacy on entrepreneurial intentions. International Journal of Entrepreneurial Behaviour and Research. https://doi.org/10.1108/IJEBR-072016-0205.

BPS-Statistic Indonesia. (2019). Keadaan Ketenagakerjaan Indonesia Februari 2019. http://www.bps.go.id.

Campopiano, G., Minola, T., \& Sainaghi, R. (2016). Students climbing the entrepreneurial ladder. International Journal of Contemporary Hospitality Management, 28(6), 1115-1136. 
Jurnal Economia, 16(2), October 2020, 143-160

https://doi.org/10.1108/IJCHM-05-2014-0236.

Cassar, G., \& Friedman, H. (2009). Does Self-Efficacy Affect Entrepreneurial Investment? Strategic Entrepreneurship Journal, 3, 241-260. https://doi.org/10.1002/sej.73.

Chaudhary, R. (2017). Demographic factors, personality and entrepreneurial inclination: A study among Indian university students. Education +Training, 59(2), 171-187. https://doi.org/10.1108/ET-02-2016-0024.

Chen, C. C., Greene, P. G., \& Crick, A. (1998). Does entrepreneurial self-efficacy distinguish entrepreneurs from managers? Journal of Business Venturing, 13(4), 295-316. https://doi.org/10.1016/s0883-9026(97)00029-3.

Chowdhury, S., Endres, M. L., \& Frye, C. (2019). The influence of knowledge, experience, and education on gender disparity in entrepreneurial self-efficacy. Journal of Small Business and Entrepreneurship, 31(5), 371-389. https://doi.org/10.1080/08276331.2018.1517474.

Dalimunthe, R. F., Zulfendri, \& Ramadini, F. (2019). The Influence of Self-Efficacy and Social Media towards the Interest of Social Entrepreneurs on Cadres of Posyandu (Maternal and Child Health Services) in Medan Labuhan Sub-district. International Conference of Organizational Innovation (ICOI 2019), 100, 602-607. https://doi.org/10.2991/icoi-19.2019.105.

Dardiri, A., Irsyada, R., \& Sugandi, M. (2019). Contributions of Understanding of Entrepreneurship, Interest in Entrepreneurship, and Self Efficacy to Entrepreneurial Readiness in the Age of the Industrial Revolution 4.0. 2nd International Conference on Vocational Education and Training (ICOVET 2018) Contributions, 242(Icovet 2018), 23-26. https://doi.org/10.2991/icovet-18.2019.6.

Do, B. R., \& Dadvari, A. (2017). The influence of the dark triad on the relationship between entrepreneurial attitude orientation and entrepreneurial intention: A study among students in Taiwan University. Asia Pacific Management Review, 22(4), 185-191. https://doi.org/10.1016/j.apmrv.2017.07.011.

Ermawati, N., Soesilowati, E., \& Prasetyo, P. E. (2017). Pengaruh Need for Achivment Dan Locus of Control Terhadap Intensi Berwirausaha Melalui Sikap Siswa Kelas Xii Smk Negeri Se Kota Semarang. Journal of Economic Education, 6(1), 66-74. https://doi.org/10.15294/jeec.v6i1.14704

Espíritu-Olmos, R., \& Sastre-Castillo, M. A. (2015). Personality traits versus work values: Comparing psychological theories on entrepreneurial intention. Journal of Business Research, 68(7), 1595-1598. https://doi.org/10.1016/j.jbusres.2015.02.001.

Farhangmehr, M., Gonçalves, P., \& Sarmento, M. (2016). Predicting entrepreneurial motivation among university students: The role of entrepreneurship education. Education and Training, 58(7-8), 861-881. https://doi.org/10.1108/ET-01-2016-0019

Farrukh, M., Alzubi, Y., Shahzad, I. A., Waheed, A., \& Kanwal, N. (2018). Entrepreneurial intentions. Asia Pacific Journal of Innovation and Entrepreneurship, 12(3), 399-414. https://doi.org/10.1108/apjie-01-2018-0004. 
Farrukh, M., Khan, A. A., Khan, M. S., Ramzani, S. R., \& Soladoye, B. S. A. (2017). Entrepreneurial intentions: the role of family factors, personality traits and self-efficacy. World Journal of Entrepreneurship, Management and Sustainable Development, 13(4), 303317. https://doi.org/10.1108/wjemsd-03-2017-0018.

Fayolle, A., \& Gailly, B. (2015). The impact of entrepreneurship education on entrepreneurial attitudes and intention: Hysteresis and persistence. Journal of Small Business Management, 53(1), 75-93. https://doi.org/10.1111/jsbm.12065.

Fayolle, A., \& Liñán, F. (2014). The future of research on entrepreneurial intentions. Journal of Business Research, 67(5), 663-666. https://doi.org/10.1016/j.jbusres.2013.11.024

Feist, J., \& Feist, G. J. (2017). Theory of Personality (Seventh Ed). McGraw Hill..

Ferreira, J. J., Raposo, M. L., Rodrigues, R. G., Dinis, A., \& Paco, A. do. (2012). A model of entrepreneurial intention: An application of the psychological and behavioral approaches. Journal of Small Business and Enterprise Development, 19(3), 424-440. https://doi.org/10.1108/14626000610705769.

Frunzaru, V., \& Cismaru, D. M. (2018). The impact of individual entrepreneurial orientation and education on generation Z's intention towards entrepreneurship. Kybernetes. https://doi.org/10.1108/K-05-2018-0272.

Fuller, B., Liu, Y., Bajaba, S., Marler, L. E., \& Pratt, J. (2018). Examining how the personality, self-efficacy, and anticipatory cognitions of potential entrepreneurs shape their entrepreneurial intentions. Personality and Individual Differences, 125, 120-125. https://doi.org/10.1016/j.paid.2018.01.005.

Garcia, P. R. J. M., Restubog, S. L. D., Bordia, P., Bordia, S., \& Roxas, R. E. (2015). Career optimism: The roles of contextual support and career decision-making selfefficacy. Journal of Vacational Behavior, 88, 10-18. https://doi.org/10.1016/j.jvb.2015.02.004.

Ghozali, I. (2017). Model Persamaan Struktural - Konsep Dan Aplikasi Dengan Program AMOS 24 Update Bayesian SEM. Badan Penerbit Universitas Diponegoro.

Hasibuan, A. H., Lubis, I., \& Rujiman. (2019). The Role of the Management of the Indonesian Young Business (HIPMI) Group in Increasing Business Interests for Young Generation in Padangsidimpuan City. International Journal of Research and Review, 6(11), 327-354.

Hemmings, J. (2018). How Psychology Works: Applied Psychology Visually Explained. In Journal of Chemical Information and Modeling (Vol. 53, Issue 9). Dorling Kindersley Limited.

Hendro. (2011). Dasar-dasar Kewirausahaan. PT. Rineka Cipta.

Hermawan, R. W., Soetjipto, B. E., \& Rahayu, W. P. (2016). The Effect of Entrepreneurial Self-Efficacy and Locus of Control on Entrepreneurship Interest through Entrepreneurship Literacy. International Organization of Scientific Research Journal of Business and Management, 18(2), 141-148. https://doi.org/10.9790/487X-1821141148 
Hsu, D. K., Burmeister-Lamp, K., Simmons, S. A., Foo, M. Der, Hong, M. C., \& Pipes, J. D. (2019). "I know I can, but I don't fit": Perceived fit, self-efficacy, and entrepreneurial intention. Journal of Business Venturing, 34(2), 311-326. https://doi.org/10.1016/j.jbusvent.2018.08.004.

Hutagalung, B., Dalimunthe, D. M. J. far, Pambudi, R., Hutagalung, A. Q., \& Muda, I. (2017). The effect of enterpreneurship education and family environment towards students' entrepreneurial motivation. International Journal of Economic Research, 14(20), 331-348. file:///C:/Users/My Computer/Downloads/References/Hutagalung et al. (2017).pdf.

Hutasuhut, S. (2018). The Roles of Entrepreneurship Knowledge, Self-Efficacy, Family, Education, and Gender on Entrepreneurial Intention. Dinamika Pendidikan, 13(1), 90105. https://doi.org/10.15294/dp.v13i1.13785.

Ibegbulam, I. J., \& Echezona, R. I. (2019). Improving the quality of human resources in academic libraries in Nigeria for the digital age : A review of competencies requirements for librarians. International Journal of Applied Technologies Libraies and Information Management, 5(April), 2-9. http://www.jatlim.org.

Indarti, N., \& Rostiani, R. (2008). Intensi Kewirausahaan Mahasiswa: Studi Perbandingan antara Indonesia, Japan dan Norway. Journal of Indonesian Economy and Business, 23(4), 369-384. https://doi.org/10.22146/jieb.6316.

Indriyani, I., \& Subowo. (2013). Pengaruh Pengetahuan Kewirausahaan dan Lingkungan Keluarga terhadap Minat Berwirausaha melalui Self-Efficacy. Economic Education Analysis Journal, 2(1), 18-23. https://doi.org/10.15294/eeaj.v8i2.31493.

Ismail, V. Y., Zain, E., \& Zulihar. (2015). The Portrait of Entrepreneurial Competence on Student Entrepreneurs. Procedia - Social and Behavioral Sciences, 169 (August 2014), 178188. https://doi.org/10.1016/j.sbspro.2015.01.300.

Joseph, I. (2017). Factors Influencing International Student Entrepreneurial Intention in Malaysia. American Journal of Industrial and Business Management, 07(04), 424-428. https://doi.org/10.4236/ajibm.2017.74030.

Karabulut, A. T. (2016). Personality Traits on Entrepreneurial Intention. Procedia - Social and Behavioral Sciences, 229, 12-21. https://doi.org/10.1016/j.sbspro.2016.07.109.

Kazeem, A. A., \& Asimiran, S. (2016). Factors Affecting Entrepreneurial Self-efficacy of Engineering Students. International Journal of Academic Research in Business and Social Sciences, 6(11), 519-534. https://doi.org/10.6007/ijarbss/v6-i11/2423.

Kerr, S. P., Kerr, W. R., \& Dalton, M. (2019). Risk attitudes and personality traits of entrepreneurs and venture team members. Proceedings of the National Academy of Sciences of the United States of America, 116(36), 17712-17716. https://doi.org/10.1073/pnas.1908375116.

Larsen, R., \& Buss, D. M. (2018). Personality psychology: Domains of knowledge about human nature (6th Editio). Mc Graw Hill Companies.

Liguori, E. W., Bendickson, J. S., \& McDowell, W. C. (2017). Revisiting entrepreneurial 
intentions: a social cognitive career theory approach. International Entrepreneurship and Management Journal, 14(1), 67-78. https://doi.org/10.1007/s11365-017-0462-7.

Locke, E. A. (1996). Motivation through conscious goal setting. Applied and Preventive Psychology, 5(2), 117-124. https://doi.org/10.1016/S0962-1849(96)80005-9.

Mahmood, T. M. A. T., Al Mamun, A., Bin Ahmad, G., \& Ibrahim, M. D. (2019). Predicting entrepreneurial intentions and pre-start-up behaviour among Asnaf millennials. Sustainability (Switzerland), 11(18), 1-26. https://doi.org/10.3390/su11184939.

Marini, C. K., \& Hamidah, S. (2014). Pengaruh self-efficacy, lingkungan keluarga, dan lingkungan sekolah terhadap minat berwirausaha siswa SMK jasa boga. Jurnal Pendidikan Vokasi, 4(2), 195-207. https://doi.org/10.21831/jpv.v4i2.2545.

Mat, S. C., Maat, S. M., \& Mohd, N. (2015). Identifying Factors that Affecting the Entrepreneurial Intention among Engineering Technology Students. Procedia - Social and Behavioral Sciences, 211(September), 1016-1022. https://doi.org/10.1016/j.sbspro.2015.11.135.

Matthew, O. J., \& Victor, A. A. (2018). Reducing unemployment in Nigeria : an evaluation of the entrepreneurship programmers in Ondo state. Journal of Studies in Management and Planning, 04(01), 26-36.

Mauer, R., Neergaard, H., \& Linstad, A. K. (2017). Self-Efficay: Conditioning the Entrepreneurial Mindset. Revisting the Entrepreneuriial Mind Inside the Black Box: An Expanded Edition, 35(February), 293-317. https://doi.org/10.1007/978-3-319-455440_19.

McClelland, D. C. (1965). Toward a Theory of Motive Acquisition. The American Psychologist, 20(5), 321-333. https://doi.org/10.1037/h0022225.

Mei, H., Ma, Z., Jiao, S., Chen, X., Lv, X., \& Zhan, Z. (2017). The sustainable personality in entrepreneurship: The relationship between Big Six personality, entrepreneurial selfefficacy, and entrepreneurial intention in the Chinese context. Sustainability (Switzerland), 9(9), 5-8. https://doi.org/10.3390/su9091649.

Memon, M., Soomro, B. A., \& Shah, N. (2019). Enablers of entrepreneurial self-efficacy in a developing country. Education + Training, 61(6), 684-699. https://doi.org/10.1108/ET-10-2018-0226.

Munawar, A. (2019). Pengaruh Pendidikan Kewirausahaan Dan Self Efficacy Terhadap Minat Berwirausaha Siswa. Prosiding Seminar Nasional Pendidikan KALUNI, 2, 398-406. https://doi.org/10.30998/prokaluni.v2i0.105.

Mustapha, M., \& Selvaraju, M. (2015). Personal Attribute, Family Influences, Entrepreneurship Education and Entrepreneurship Inclination among University Students. Kajian Malaysia, 33(1), 155-172.

Okoro, C. N., Amaechi, E. C. C., \& Chijioke-Okoro, C. G. (2019). Achieving Reduction in Unemployment and Labour Conflicts: The Cooperative Model. Forshen Hub International Journal of Economics and Business Management, 1(1), 39-56. 
Osakede, U. A., Lawanson, A. O., \& Sobowale, D. A. (2017). Entrepreneurial interest and academic performance in Nigeria: evidence from undergraduate students in the University of Ibadan. Journal of Innovation and Entrepreneurship, 6(1). https://doi.org/10.1186/s13731-017-0079-7.

Palmer, C., Fasbender, U., Kraus, S., Birkner, S., \& Kailer, N. (2019). A chip off the old block? The role of dominance and parental entrepreneurship for entrepreneurial intention. Review of Managerial Science. https://doi.org/10.1007/s11846-019-00342-7.

Phillips, J. M., \& Gully, S. M. (1997). Role of goal orientation, ability, need for achievement, and locus of control in the self-efficacy and goal-setting process. Journal of Applied Psychology, 82(5), 792-802. https://doi.org/10.1037/0021-9010.82.5.792.

Piperopoulos, P., \& Dimov, D. (2014). Burst Bubbles or Build Steam? Entrepreneurship Education, Entrepreneurial Self-Efficacy, and Entrepreneurial Intentions. Journal of Small Business Management, 53(4), 970-985. https://doi.org/10.1111/jsbm.12116.

Pizzorno, M. C., Benozzo, A., Fina, A., Sabato, S., \& Scopesi, M. (2014). Parent-child career construction: A narrative study from a gender perspective. Journal of Vocational Behavior, 84(3), 420-430. https://doi.org/10.1016/j.jvb.2014.03.001.

Popescu, C. C., Bostan, I., Robu, I. B., Maxim, A., \& Diaconu (Maxim), L. (2016). An analysis of the determinants of entrepreneurial intentions among students: A Romanian case study. Sustainability (Switzerland), 8(8), 1-22. https://doi.org/10.3390/su8080771.

Ramayah, T., \& Harun, Z. (2005). Entrepreneurial Intention among the Student of Universiti Sains Malaysia (USM). International Journal of Management and Entrepreneurship, 1, 8-20.

Ratumbuysang, M. F. N. G., \& Rasyid, A. A. (2015). Peranan orang tua, lingkungan, dan pembelajaran kewirausahaan terhadap kesiapan berwirausaha. Jurnal Pendidikan Vokasi, 5(1), 15-26. https://doi.org/10.21831/jpv.v5i1.6058.

Rokhman, W., \& Ahamed, F. (2015). The role of social and psychological factors on entrepreneurial intention among islamic college students in Indonesia. Entrepreneurial Business and Economics Review, 3(1), 29-42. https://doi.org/10.15678/EBER.2015.030103.

Sabiu, I. T., Abdullah, A., Amin, A., \& Tahir, I. M. (2018). An empirical analysis of the need for achievement motivation in predicting entrepreneurial persistence in Bumiputra entrepreneurs in Terengganu, Malaysia. International Journal of Business and Globalisation, 20(2), 190-202. https://doi.org/10.1504/IJBG.2018.089867.

Şahin, F., Karadă̆, H., \& Tuncer, B. (2019). Big five personality traits, entrepreneurial selfefficacy and entrepreneurial intention: A configurational approach. International Journal of Entrepreneurial Behaviour and Research, 25(6), 1188-1211. https://doi.org/10.1108/IJEBR-07-2018-0466.

Sani, A., \& Bin Jamil, H. (2019). Graduates' Employability through the University Entrepreneurship Curriculum Implementation: The Malaysian Context. Science 
Proceedings Series, 1(1), 12-15. https://doi.org/10.31580/sps.v1i1.512.

Santos, S., \& Liguori, E. W. (2019). How and When Is Self-Efficacy Related To Entrepreneurial Intentions: Exploring the Role of Entrepreneurial Outcome Expectations and Subjective Norms. Revista de Estudios Empresariales. Segunda Época, 1(1), 6-21. https://doi.org/10.17561/ree.v2019n1.1.

Schmutzler, J., Andonova, V., \& Diaz-Serrano, L. (2019). How Context Shapes Entrepreneurial Self-Efficacy as a Driver of Entrepreneurial Intentions: A Multilevel Approach. Entrepreneurship: Theory and Practice, 43(5), 880-920. https://doi.org/10.1177/1042258717753142.

Sheldon, K. M., Prentice, M., \& Osin, E. (2019). Rightly crossing the Rubicon: Evaluating goal self-concordance prior to selection helps people choose more intrinsic goals. Journal of Research in Personality, 79, 119-129. https://doi.org/10.1016/j.jrp.2019.03.001.

Slameto. (2010). Belajar dan Faktor-Faktor Yang Mempengaruhi. PT. Rineka Cipta.

Solesvik, M. Z. (2017). A Cross-National Study of Personal Initiative as a Mediator between Self-Efficacy and Entrepreneurial Intentions. Journal of East-West Business, 23(3), 215237. https://doi.org/10.1080/10669868.2017.1306821.

Soomro, B. A., \& Shah, N. (2015). Developing Attitudes and Intentions Among Potential Entrepreneurs. Journal of Enterprise Information Management, 28(2), 304-322. https://doi.org/10.1108/JEIM-07-2014-0070.

Tong, X. F., Tong, D. Y. K., \& Loy, L. C. (2011). Factors Influencing Entrepreneurial Intention Among University Students. International Journal of Social Sciences and Humanity Studies, 3(1), 487-496.

Utsch, A., \& Rauch, A. (2010). Innovativeness and initiative as mediators between achievement orientation and venture performance. European Journal of Work and Organizational Psychology, 9(1), 45-62. https://doi.org/10.1080/135943200398058.

Viinikainen, J., Heineck, G., Böckerman, P., Hintsanen, M., Raitakari, O., \& Pehkonen, J. (2017). Born entrepreneurs? Adolescents' personality characteristics and entrepreneurship in adulthood. Journal of Business Venturing Insights, 8, 9-12. https://doi.org/10.1016/j.jbvi.2017.05.001.

Wang, D., Wang, L., \& Chen, L. (2018). Unlocking the influence of family business exposure on entrepreneurial intentions. International Entrepreneurship and Management Journal, 14(4), 951-974. https://doi.org/10.1007/s11365-017-0475-2.

Wartiovaara, M., Lahti, T., \& Wincent, J. (2019). The role of inspiration in entrepreneurship: Theory and the future research agenda. Journal of Business Research, 101, 548-554. https://doi.org/10.1016/j.jbusres.2018.11.035.

Wright, S. L., Perrone-Mcgovern, K. M., Boo, J. N., \& White, A. V. (2014). Influential factors in academic and career self-efficacy: Attachment, supports, and career barriers. Journal of Counseling and Development, 92(1), 36-46. https://doi.org/10.1002/j.15566676.2014.00128.x. 
Jurnal Economia, 16(2), October 2020, 143-160

Wu, W., Wang, H., Zheng, C., \& Wu, Y. J. (2019). Effect of narcissism, psychopathy, and machiavellianism on entrepreneurial intention-the mediating of entrepreneurial selfefficacy. Frontiers in Psychology, 10(FEB). https://doi.org/10.3389/fpsyg.2019.00360

Yanti, P. E. D., Nuridja, I. M., \& Dunia, I. K. (2014). Pengaruh lingkungan keluargaTerhadap Berwirausaha Siswa Kelas XI Smk Negeri 1 Singaraja. Economic Education Analysis Journal, 4(1), 1-11.

Yimamu, N. (2018). Entrepreneurship and Entrepreneurial Motivation. Centria University of Applied Sciences.

Youssef, E. A. I. M., Nafii, I., \& Kamal, A. (2018). Entrepreneurial Spirit of Students: Innate or Acquired. In: Tipurić, Darko Labaš, Davor (Ed.): 6th International OFEL Conference on Governance, Management and Entrepreneurship. New Business Models and Institutional Entrepreneurs: Leading Disruptive Change., 332-343.

Yuhendri, L. V. (2014). Pengaruh Kebutuhan Akan Prestasi, Lokus Kendali, Dan Efikasi Diri Terhadap Minat Berwirausaha Mahasiswa Fakultas Ekonomi Universitas Negeri Padang. Jurnal Penelitian Pendidikan, 14(1), 54-61.

Zeffane, R. (2013). Need for Achievement, Personality and Entrepreneurial Potential: a Study of Young Adults in the United Arab Emirates. Journal of Enterprising Culture, 21(01), 75-105. https://doi.org/10.1142/s0218495813500040.

Zhou, Y., Yin, H., Wang, M., \& Wang, J. (2018). The effect of family-focused psychoeducational therapy for autism spectrum disorder children's parents on parenting self-efficacy and emotion. Archives of Psychiatric Nursing, 33(1), 17-22. https://doi.org/10.1016/j.apnu.2018.08.002. 